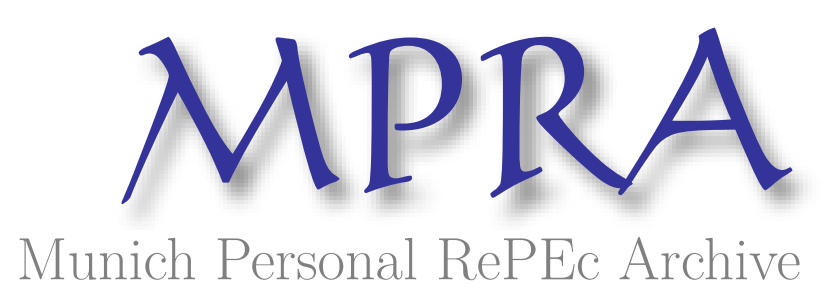

\title{
Electoral and political reforms
}

\author{
Varma, Vijaya Krushna Varma
}

30 January 2013

Online at https://mpra.ub.uni-muenchen.de/111988/

MPRA Paper No. 111988, posted 18 Feb 2022 06:30 UTC 

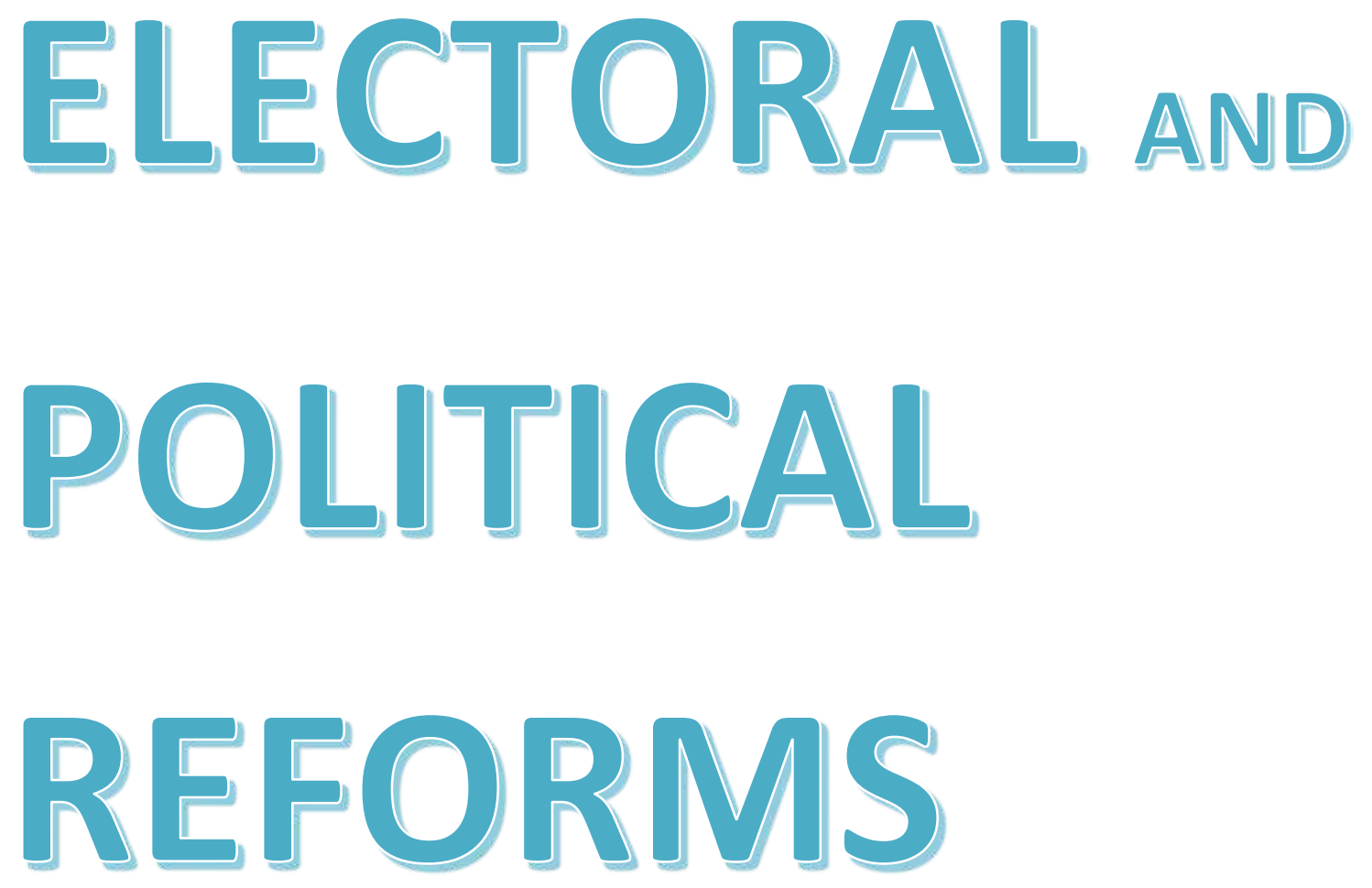


\section{Electoral and Political reforms in India}

VIJAYA KRUSHNA VARMA

Electoral and political reforms are urgently needed to reserve politics only to purists who intend to dedicate their whole time and energy to serving the people of the country round the clock. It is imperative to consider these new political and electoral reforms for a better, healthy and improved democracy to remove corruption, inequalities, unemployment and misgovernance.

As we are on the threshold of completing 75 years of independence, electoral and political reforms are to be put on a fast track to bring transparency, accountability, efficacy and high-speed response into governance; to meet the aspirations of the people and to relive the Rama Rajya. Zero corruption government should be the bedrock of an advanced democracy. We need to restructure and reboot the present electoral and political formats, into more responsive entities to enable the formation of honest, efficient and stable governments at centre and in states.

\section{Salient features of these new political reforms}

1 Full time representation

2. Fixed time table for assembly and parliament sessions

3. Compulsory attendance in parliament and assemblies

4. Compulsory attendance in constituencies

5. One person, one office, one job, one responsibility

\section{Electoral reforms: ---}

1. Recognition of political parties

2. Registration of political parties

3. Independent candidates and non-recognised parties

4. Disqualifications

5. Functioning of political parties

A] One person, one office, one job, one responsibility

B] Full time representation

6. Functioning of Legislatures
A] Fixed time table for assembly and parliament sessions
B] Compulsory attendance in parliament and assembly sessions
C] Compulsory attendance in constituencies

7. Government formation
A] State
B] Centre

8. Transparent governance

9. Tenure of legislatures and local bodies

10. Four tier Representation structure

\section{$1 \quad$ Recognition of political parties}

I suggest the following conditions for recognition as a national party, a regional party and a state party. The Central election commission should have the following powers to recognise and derecognise the political parties. 
1. The parties which got a minimum of $10 \%$ or more of the total votes polled in the last general elections held for Lok Sabha shall be treated as national parties.

2. If only one party got $10 \%$ or more of total votes polled, the next party which got more percentage of votes below $10 \%$ shall be treated as a national party and it will become the opposition party in the Lok Sabha.

3. If no party gets $10 \%$ or more of total votes polled, then the first two parties which got the highest percentage of votes shall be treated as national parties; it is an unlikely scenario.

4. If any party which got less than $10 \%$ of total votes polled at all India level but received more than $10 \%$ votes each in two or more states, it shall be given the regional party status.

5. The party, which got a minimum of $10 \%$ or more of total votes polled in either assembly or Lok Sabha elections in that state, shall be given state party status.

6. If only one party got $10 \%$ or more of total votes polled, the next party which got more percentage of votes below $10 \%$ shall also be treated as a state party and it will become the main opposition party in the assembly. 7. Only the recognised political parties should be allowed to contest elections on common symbols. In literal sense there will be a maximum of five national parties at the national level and five recognised parties at State level.

\section{Recognition of new political parties}

There shall be two methods for a new political party to be recognised as a national party or as a state party.

The first method is by enrolling members first and getting recognised as a national party or as a start party before participating directly in the main polling for assembly and Lok Sabha elections.

The second method is by participating in preliminary online polling, and, if passed, can contest in the main polling for assembly, and Lok Sabha elections. It is the easiest method for the new party to get recognised as a national party or a state party and contest elections with a common symbol.

\section{First Method}

1. If an individual or a group of people wants to form a national party, a regional party or a state party, they should approach the Election commission of India for registration of a political party. It will be registered as a national, regional or state party, according to its registration. But common symbols will not be given upon registration. Mere registration of a political party shall not give it the right to contest elections directly at the main polling. The registered parties will have to get recognised to contest elections. It has to get recognition within one year of its registration.

2. To get national party status and contest elections in the main polling on common symbols, it should be made mandatory to enrol at least $5 \%$ of the national electorate as its members with membership fee of Rs. 10 for each member. The total membership amount received from $5 \%$ of the national electorate should be deposited at the Election commission of India. Then the party will be given recognition as national party status and will be allotted an available symbol of its choice. From then on it can contest Lok Sabha elections or state elections as a national party on a common symbol. If the newly recognised party fails to get a minimum of $10 \%$ of total votes polled at all India level in the first general election, it will be de-recognised as a national party. If the party gets $10 \%$ or more votes of total votes polled in one or more states, then it will be recognised as a regional party ( 2 or more states) or state party (1 State). It will be allowed to contest in those States (assembly or Lok Sabha seats) where it got more than $10 \%$ or more of total votes polled. If any newly registered national party gets more than $10 \%$ votes at national level in the first general elections it contested, then the deposited amount will be credited into the party's account.

3. If the newly recognised party failed to get a minimum of $10 \%$ of the total votes polled in the first general elections it contested, it would lose its national party status and the right to contest Lok Sabha elections once again. It will have to start from the beginning. That means it will have to enrol $5 \%$ of 
the national electorate, with Rs 10 from each voter as membership and deposit that total amount at the Election commission of India.

4. To get state party status and contest elections, it should be made mandatory for a new party to enrol at least $5 \%$ of the electorate in that state with a membership fee of Rs 10 each from its member. The total subscription amount received from $5 \%$ of the state electorate should be deposited at the Election commission of India. Then the party will be given state party status and will be allotted an available symbol of its choice. From then on it can contest assembly elections or Lok Sabha seats of that state as a state party in the main polling. If the state party does not get $10 \%$ of the total votes polled in the election for that state assembly, it should be de-recognised and its symbol also be frozen. If the elections are held simultaneously for both assembly and parliament elections, and the state party gets at least $10 \%$ votes either for assembly or Lok Sabha seats, it will retain its state party status even though it does not get a minimum $10 \%$ votes either in assembly or Lok Sabha elections. This requirement of $10 \%$ vote share is applicable to either assembly or Lok Sabha elections in that state. Even if a state party gets less than $10 \%$ votes in Lok Sabha seats of that state, it will retain its state party status until the coming state assembly elections where it should get the mandatory minimum $10 \%$ vote share. If the state party does get less than $10 \%$ vote share in assembly elections, the party will be de-recognised by the Central Election Commission. It will have to enrol $10 \%$ of the state electorate to get recognition once again. That means for state parties, the $10 \%$ vote share is not mandatory in Lok Sabha elections. The state parties can contest both Lok Sabha and assembly elections in the states where they got recognition, as long as they maintain a minimum $10 \%$ vote share either in assembly election or Lok Sabha election.

5. To get Regional party status and contest elections, it should be made mandatory to enrol at least $5 \%$ of the electorate in 2 or more States with membership fee of Rs 10 each from members. The total subscription amount obtained from $5 \%$ of the electorate of 2 or more States, should be deposited at the Election commission of India. Then the party will be given the Regional party status and the available symbol of its choice. From then on, it can contest assembly or parliament seats of those States as a Regional party. For State parties and Regional parties, the $10 \%$ vote share is not mandatory in Lok Sabha elections. They can contest both Lok Sabha and assembly elections in those States where they got recognition as long as they maintain minimum $10 \%$ vote share in every assembly election in those states where they are recognised.

\section{Second method for registered parties and independent for participating in assembly and Lok Sabha elections}

Through the second method, newly formed political parties can contest elections without enrolling party members as in the first method. It is the easiest method to get recognised as a national party or state party.

1. When the Election Commission issues a notification for general or state elections or for both, only the recognised national, regional, and state parties can contest elections directly in the main polling by EVMs. There will be a preliminary online polling for the newly registered parties and independents for qualifying into main polling. The registered parties can contest elections by putting candidates in all or in some seats as they like. The winners of this preliminary online polling in each constituency will participate in the main polling by EVMs along with registered party candidates.

2. Once the nomination process, the scrutiny process and the withdrawal process is over, the valid nominations will be declared. Now, preliminary online polling will be held on the web, mobile web and social media using Election Commission's apps for independent candidates and non-recognised parties. The elections commission shall allot a common symbol for non-recognised parties. The time period for campaigning shall be 10 days. People can vote for registered candidates or independent 
candidates through online, via internet centres or from smartphones or e-seva centres during this entire campaigning period of 10 days. The voting app on smartphones enables the voter either with face recognition/finger print scan or OTP with the registered mobile number. That means no voter can vote twice online. Online voting should be open day and night for 10 days. After 10 days of continuous online voting, the winner among the independent candidates and non-recognised parties from each constituency will be declared. The winner will be added to the main contest, where only registered parties are allowed. The main polling will be held after 5 days. Hence, a maximum of 5 candidates will be in the fray for the main polling. So EVMs can be made in compact and uniform size for all assembly and parliament seats. All eligible voters shall go to polling booths to cast their votes through EVMs although they participated in online preliminary polling for independent candidates. They can have liberty to vote for one candidate in online voting and vote for another candidate in the main Polling. The preliminary online polling is absolutely necessary for avoiding non-serious independent candidates. With so many independent candidates in the fray in some constituencies, the conduct of polling is becoming difficult with large EVMs. The large number of non-serious candidates makes it necessary for large EVMs confusing voters to find their symbol.

I will explain to you in a simple way by giving an example of election notification.

Date of election announcement and Election code of conduct

Date of notification

Date of receiving nominations

Last date for nominations

Date of scrutiny

Last date of withdrawal

Online polling date for independents and non-recognised parties

Last date of online polling

Date of announcement of winners from independent candidates

Polling date for main elections

Date of results announcement
$1-5-2021$

$5-5-2021$

9- 5-2021

$15-5-2021$

$16-5-2021$

$19-5-2021$

21-5-2021

29-5-2021

$30-5-2021$

6-6-2021

8-6-2021

3. If the registered party gets $10 \%$ or more of the total votes polled in the main election, it will be recognised as state, regional or national party according to its participation. It will get a permanent election symbol. It needs not go through preliminary online polling in the next elections. It does not need to go through the membership route to get recognised. If it gets less than $10 \%$ of votes in the next elections, it will get de-recognised and will have to contest the next elections once again either through a preliminary round or through membership drive by enrolling $10 \%$ of the electorate.

4. If the independent candidate gets $10 \%$ or more of total votes polled, even though he/she was defeated, he/she will be eligible to contest election from that constituency next time also whenever elections come without needing to go through preliminary online voting. The candidate's eligibility to participate in the main polling, along with recognised parties, will be valid as long as he/she gets either elected or gets minimum $10 \%$ votes polled in each election in that constituency.

5. This rule should not be applied to SC/ST reserved assembly or parliament seats. They can contest elections, as in the present system, in reserved SC/ST assembly or parliament seats. The independents (SC/ST candidates) will have to make a security deposit Rs 5000 for assembly seat or Rs.10000 for parliament seat.

6. The contesting candidates should open a separate bank account for election purposes in any private or public commercial bank. He/she should be allowed to take funds for election campaigns from individuals or industries or organisations through cheque or online money transfers only. He/she 
should not be allowed to take money, in cash form, for election campaigns from individuals or industries or organisations.

7. He/she should spend for election campaigns through cheque or online money transfer only. Only this separate bank account should be used for taking funds or spending for election campaigns.

8. The bank statement should be submitted to the Election Commission of India within one week of the last date of counting.

9. There shall be no expenditure limit for election campaigns. But should not distribute money, liquor, provisions, gift articles, vehicles, consumer goods, etc. after election notification is issued. There shall be no upper limit for candidates for campaigning through electronic and print media, and social media. There shall be no upper limit for spending on meals for party workers during the entire period of campaigning. There should be strict restrictions on usage of vehicles, banners, and flags.

10. The remaining election fund, if any, in his/her account after elections should not be utilised for his/her personal purpose. That means money collected for election campaigns should be utilised only for election campaigning but not for his/her personal usage. This remaining election fund can be utilised in the next election if he/she intends to contest.

11. If he/she does not want to contest once again then he/she should hand over the remaining election fund to the Election Commission of India.

12. If any candidate collects funds in cash form from individuals/industries/ organisations or spends money in cash form, then the Election Commission of India should have the absolute right not only to debar that candidate from contesting elections but also confiscate and auction all his/her assets. Note - General elections can be held on a single day in a single phase by using Touch Screen Voting Machines. You can now this under the item "Touch Screen Voting Machines".

\section{Disqualifications}

The election commission of India should have absolute powers to disqualify MLA/MPs if they do not complete their terms for one reason or other.

1. No person should be allowed to contest from more than one constituency simultaneously. No $\mathrm{MLA} / \mathrm{MP} / \mathrm{may}$ r/panchayat president or any elected representative shall be allowed to contest another election till his/her term of incumbent office expires.

2. MLAs and MPs should complete their full term or up to the dissolution of the assembly or Lok Sabha. If any MLA/MP resigns his/her seat midway through to the actual term, he/she should not be allowed to contest any other election conducted by the State election commission or election commission of India for Centre and State elections until the actual term of his/her office to which he/she had been elected ends.

3. MLAs/MPs should remain in the same parties until the completion of the full term of office. They should vote, according to their party's whips. If they violate party whips against their parties, they should be immediately disqualified by the state election commission/ECOI upon the request from the parties they belong to. They should not be allowed to contest by-elections or any election, until the actual term of assembly or Lok Sabha to which he/she had been elected ends.

4. If any party thinks that their elected representative [MLA/MP] is acting or functioning in violation of their respective parties' policies, guidelines or rules, the party should have the right to ask the Speaker of the assembly in case of MLA, or Lok Sabha speaker in case of its MP to disqualify the representative immediately. The party president and more than half of its MLAs should go to the speaker of the assembly office and submit a written request form duly signed by the party president and more than half of the party MLAs. For example, if the party has 12 MLAs, it is necessary for the physical appearance of 7 MLAs along with the party president. The assembly speaker shall have the authority to disqualify the MLA immediately. If the assembly speaker does not oblige the party request immediately for one reason or the other, then the party president, along with MLAs, shall go to the state election commission office for seeking the disqualification of their party MLA in the same procedure as said earlier. The state election commissioner shall have the right to disqualify the MLA 
immediately without giving any notice to the concerned MLA upon the request from that political party for violation of party code of conduct. In that case, the disqualified representative will have the right to contest from that constituency in the subsequent by-election or any other election. Similarly, the disqualification of an MP of a party can be done by the party president and more than half of the strength of party MPs, either by requesting the Speaker of the Lok Sabha or the chief election commissioner. Here also the physical appearance of the party president and half of its MPs shall be mandatory for seeking disqualification of their MP/MPs. The disqualified MP can be allowed to contest by elections.

5. But he should not be allowed to contest in the by-election or any election till the full term finishes or dissolution of the house to which he/she had been elected in case A] if he/she resigns on his own B] if he/she votes against the party's whip in the assembly or parliament pertaining to no confidence/confidence vote or other voting like bills, amendments etc., till the full term expires or dissolution of the house.

6. The state election commissions should have absolute powers to conduct elections for panchayats, cooperatives, municipalities, and corporations on schedule as like assembly and parliament elections. Elections for all local bodies should be held at least 15 days before the term of the present bodies' ends. If for one reason or the other, the elections to the local bodies need to be postponed, then the postponement for six months should be ratified by the assembly with a simple majority.

7. It should be mandatory to hold elections for local bodies before the stipulated period or term of the local body ends. No local body should be allowed to run without elected representatives for more than 4 months. If any representation to any local body falls vacant either due to resignation, suspension or death of a representative, re-elections should be held by the State Election Commission within four months from the date of vacancy.

8. Bye-elections to all vacancies in assembly or Lok Sabha, caused due to resignations, disqualifications or deaths should be conducted thrice during a year, at the gap of four months each. No MLA or MP seat should be left unoccupied for more than four months.

\section{$5 \quad$ Functioning of political parties}

\section{Collection and maintenance of party funds.}

1. The political parties should be allowed to take party funds from individuals, industries and organisations through cheques and online money transfers only.

2. The political parties should be banned from accepting party funds in cash form from individuals, industries or organisations. It should be made mandatory for political parties to put their party fund accounts on websites. The daily incoming funds and party expenditure should be updated daily on their party websites with net available party funds on each day.

3. Every political party should be allowed to manage their party funds from only one account in any commercial bank. All donations and party funds should be taken only through this account and through cheques or online money transfers. The list of donors should be displayed on the respective party websites. No political party should be allowed to collect party funds from foreign countries. Party funds should be collected only from within the country.

4. Party funds should be expended through cheques and online money transfers only. The political parties should not be allowed to withdraw money in cash form from their accounts. That means there should be only one bank account for one party to accept and spend party funds.

5. All political parties should submit their party assets [party offices, buildings, plots, flats, and building area], that are situated in the entire country, to the Election Commission of India. All the party assets in all forms should be displayed on their websites. Any new addition of party assets in any form should be updated daily on websites.

6.. If any party takes party funds in cash form from individuals/industries/ organizations or spends money in cash form, then the Election Commission of India should have the absolute right to 
derecognise that political party and seize that party's fund and confiscate and auction all its assets within one month.

7. There shall be no upper limit for spending, for promotion of the party or its candidates through electronic and print media, and on social media.

8. Political parties should be derecognised and debarred if they are found to be taking funds from foreign countries. No funds from foreign parties, institutions, industries or individuals should be allowed.

9. Indian political parties should not have any contacts with foreign political parties.

\section{One person, one office, one post, one responsibility}

Separation and sharing of power between the executive and legislature is the key to the proper functioning of democracy. The levers of power should not be concentrated in one person. The political system should be delinked from government and governance. In the present system, the same people are running the party, running the government and running their own businesses, industries or organisations. The persons who are managing or heading their parties are also running the government and at the same time, representing the people and campaigning for the party in the elections. In every election, the Prime Minister, the Chief Ministers, the ministers, the MP's, the MLA's are concentrating on the selection of candidates and election campaigning while throwing the representation, the governance and the administration to the winds. The quality of administration is being affected. Varma suggests that the running of political parties, administering governments and the people's representation should be separated and held by different sets of people.

1. Functioning of the party, representation of the people and administration of the government should be done by different sets of people. That means the same person should not hold different positions at the same time. The running of the party, the running of the government and representing the people should be done by different persons.

2. Those that represent the people should not run any party or government. Those who run the party should not be part of the government or be representatives of the people. Those who administer the government should not hold any other responsibility.

3. The Prime Minister or Chief Minister and ministers shall participate in government programmes or functions only. They should not be allowed to participate in any party-held programmes, meetings, rallies, events, etc. As long as they are in office, they should not be allowed to campaign physically for the party at any time and during elections. They can canvass on behalf of their party through print and electronic media, and social media. Their only responsibility is governance and administration. They should concentrate solely on the administration of government and nothing else.

4. Political leaders who run or head political parties should not be allowed to contest elections. They can contest elections after resigning from their party posts. If they are not elected by the people, they can regain their party posts.

Central and state government employees can contest elections only if they have resigned from their jobs six months before election notification is issued. They should not be allowed to get their jobs back if they are defeated in the elections.

5. The party leaders, the party functionaries, and all party members can campaign for their candidates in the entire country.

6.. The political leader can also become Prime Minister or Chief Minister or minister if they resign from their party posts before taking the oath of secrecy. The political leader can either run the party or head the government, but cannot hold two positions at the same time. This style of function is envisaged to usher in good governance with full concentration on the job he holds.

7. Political parties, which have a majority in the legislature, shall choose one of the party members to head the government who are not legislative members or functionaries of the party. The political 
parties can declare their candidates as Prime Minister or Chief Minister before elections. The declared candidates should not contest elections. If the declared candidates are incumbent Prime Minister or Chief Ministers from ruling parties, they should not campaign physically by participating in public rallies, roadshows, etc. They can campaign through electronic, print, and social media. If the declared Prime Minister, Chief Minister and ministers candidates are from opposition parties and who are not holding any public or private office, can campaign on behalf of their parties through elections rallies, roadshows, electronic and print media, and social media.

8. The persons who represent the constituency, the persons who run the party and the persons who run the government should be different. That means a person who represents people cannot run the party and run the government at the same time. It is decentralisation of power, sharing of responsibilities, distribution of work, and the justification of democracy.

9. Persons who hold party positions should not be allowed to administer the government. The parties, which won the majority, can nominate able, efficient, honest and hardworking persons as Prime Minister, Chief Minister or minister, who are all within eligible criteria (as described earlier) from the various fields to run the government. This selected group of ministers will run the government according to the party's directions, policies, advice, and manifestoes. The party president can attend the cabinet meetings and have their say in all government decisions.

10. The chief minister or the Prime Minister should run the government on the advice, directions and policies of the Party. The party will have the power to change either the chief minister or minister at any time and replace him with another able and honest person to head the ministry. But whenever the chief minister is changed, ministers do not need to resign. Only the new chief minister will take the oath of office.

\section{Code of conduct for political leaders}

1.. The political leaders can run the party, hold public meetings, rallies, peaceful agitations, demonstrations and all other party work without causing any inconvenience to the general public.

2. Political leaders, non-government organisations and social activists can give bandh calls to people against government policies through electronic and print media, and social media. It should be left to the people to decide whether they participate voluntarily or not.

3. They should not be allowed to forcefully close shops, obstruct traffic movements, train movements, etc. Political leaders should not encourage their party workers to forcefully close shops, obstruct any business or social activity, or rail and road movements.

4. The election commission will have the absolute right to derecognise any political party if the leaders of that political party forcefully close shops, obstruct traffic movements, train movements etc., People who forcefully close shops, obstruct road and rail movements, etc. should be debarred from contesting any elections. Only law-abiding citizens shall have the right to contest elections.

5. The right to peaceful living, the free movement of people should not be violated by political leaders, parties, and organisations.

6. Political leaders and social activists can stage protests, dharnas, etc. against government policies, acts or misgovernance without causing inconvenience to public life. Public activity cannot be disrupted in the name of protests and agitations.

\section{Eligibility rules for Prime Ministers, Chief Ministers, Ministers, MPs, MLAs, and speakers.}

1. They must be Indian-born citizens. Their spouses also should be Indian-born citizens.

2. They and their spouses should not have any movable or immovable properties, bank accounts in any foreign country and they should not have any shares in foreign countries. 
3. They should not hold any position in any private companies. They should not head any government or private trust or organisation during their term in office.

4. Those who are bank loan defaulters above one crore rupees should be debarred from holding any public office, including Prime Minister, Chief Minister, minister, etc.

Those industrialists, business people and contractors, who have borrowed loans and are involved in compromise settlement of non-performing loans of more than one core with any government or private bank, should be debarred from contesting any election and holding any public office. They should not be allowed to head and lead any political party. Good financial discipline should be the primary requisite for any person to contest any election.

5. They and their spouses, who have written off their bank loans of over one crore during their lifetime should be debarred from contesting elections. Those, who have taken financial haircuts of more than one crore in one-time settlement with any government or private banks on their outstanding loan amounts, should be debarred from contesting elections.

6. They and their spouses should not have failed in paying loan instalments for more than six months.

7. They and their spouses' credit scores should be good. Those who have bad credit scores should be debarred from holding public offices.

8. They should never have got any foreign citizenship and resided in foreign countries for more than one year.

9. The candidates should declare their assets [all movable, immovable properties, bank balances, shares and other investments belonging to them, spouses, dependent children and family members] and submit to the Election Commission along with the application to contest elections. If he/she gets elected, monthly updates of assets [bought or sold] should be submitted to the election commission

\section{Full time representation: -}

1. There should be a paradigm shift from part time representation to full time representation. The minimum condition for any person to contest elections is that he/she must agree to full time representation of his/her constituency.

2. MPs and MLAs should not hold any other office. He/she should not become Prime Minister, Chief Minister or ministers. He should not head any organisation, trust, corporation, society, establishment, company or institution-private or public during their term in office as people's representative. He/she should not be a member of any organisation, trust, corporation, society, establishment, company or institution, private or public.

3. The people who hold shares in a company that has defaulted on bank loans should not be allowed to contest elections. People who themselves are bank loan defaulters above one crore rupees should be debarred from contesting any election. Those and whose spouses have written off their bank loans during their lifetime should not be allowed to contest elections.

4. He/she should spend his/her full term in his/her constituency when there is no assembly or parliament session in progress.

5. He/she should not be allowed to practice another profession, job or post during his/her term.

6. He/she should be always available to people in his/her constituency. He/she should see that all public services like health care, drinking water, education, sanitation, etc., are available to the people in his/her constituency. Any deficiency in these services should be brought to the notice of the legislature, government, and the party.

7. He/she should not be allowed to canvass for his party or other candidates outside his/her constituency. But he/she can canvass in his/her constituency.

8. He/she should not be allowed to hold public meetings, rallies, either for his/her party or for other candidates outside his/her constituency. But he/she can hold public meetings, rallies, either for his/her party or for his/her constituency.

9. He/she should not be allowed to visit foreign countries during his/her term. 
10. He/she wants to go to any foreign country for either medical treatment or for any other purpose; he/she should resign before going to any foreign country.

\section{Functioning of Legislature}

\section{A] Fixed time table for assembly and parliament sessions}

There should be a fixed time table for both assembly and parliament sessions.

1. The parliament session should be held every month from the $1^{\text {st }}$ to the $12^{\text {th }}$ day of each month, with every Saturday and Sunday being holidays. If any holiday falls between these days, one additional day should be added beyond $12^{\text {th }}$ of that month. That means there will be 12 parliament sessions, 120 sitting days per year.

2] The assembly sessions should be held every month from the $1^{\text {st }}$ to the $12^{\text {th }}$ day of every month. There will be 12 assembly sessions with 120 sitting day per year, instead of three sessions in the present parliamentary system. During general elections, one session can be skipped for parliament and one assembly session can be skipped during assembly elections.

\section{B] Compulsory attendance in constituencies}

2. The MP should be in his/her constituency from $16^{\text {th }}$ to the end of each month. If he/she wants to go out of his constituency, he/she should take leave from the speaker. The total number of leave days should not exceed 54 days per year. If the leave days exceed more than 54 days per year [excluding leave on health grounds] the speaker shall have the right to disqualify him/her permanently. He/she should not be allowed to contest elections in his/her lifetime once again. The Central government should construct a residential quarter and office for MPs in each Loksabha constituency.

3. The MLA should be in his/her constituency from $15^{\text {th }}$ day to the end of each month. If he/she wants to go out of his constituency, he/she should take leave from the speaker. The total number of leave days should not exceed 54 days per year. If the leave days exceed more than 54 days per year [excluding leave taken on health grounds], the speaker shall have the right to disqualify him/her permanently. He/she should not be allowed to contest elections in his/her lifetime once again. The state government should construct a residential quarter and office for each MLA in the respective constituencies.

4. The MPs and MLAs should vacate their quarters within 2 months after the end of their tenures. The ex-MPs and ex-MLA s should be given permanent quarters in their respective constituencies only, if they fulfil the following conditions.

a. They must complete their full term of 4 years.

b. They should not have defected to other parties.

c. They should have more than $80 \%$ attendance in Assembly or Lok Sabha and $80 \%$ attendance in their respective constituencies.

d. They should not have walked out of legislatures during their entire tenure of representation.

e. They should not have received more than three warnings from the speaker of the house for obstructing the functioning of legislatures.

f. They should not have been disqualified by the speaker or resigned during the middle of their term of representation.

g. Their annual income is less than 50 lakhs per annum.

h. The ex-MLAs and ex-MPs shall not deserve the permanent quarter in their constituencies, if they have their own house or apartment anywhere in the country.

j. The ex-MLSs and ex-MPs shall be eligible for lifetime pensions if they fulfil all the above conditions. 


\section{C] Compulsory attendance in parliament and assemblies}

1. It should be made mandatory for every MLA or MP to have $70 \%$ attendance every year.

2. It should be made mandatory for every MLA or MP to present $70 \%$ of total session time per year in the assembly or parliament.

3. Every walkout from the assembly or parliament should be treated as an absence.

4. If any MLA or MP fails to maintain $70 \%$ attendance of days and time during a year, except on health grounds, he/she should be disqualified and should not be allowed to contest elections in his/her lifetime once again.

5. If any member obstructs or goes to the speaker's podium, either in assembly or parliament, the speaker shall have the right to suspend him for one day. If he/she repeats the obstruction for a second time, the speaker shall have the right to suspend him for the entire session. If he/she repeats the obstruction for the third time during his/her entire term, the speaker shall have the right to disqualify him/her permanently. He/she should not be allowed to contest elections in his/her lifetime once again. Repeated disruption of parliament or assembly shall not be tolerated. Frequent disruptions of the assembly or parliament will come to an end. It has become a routine exercise for the opposition parties to stall proceedings of the assembly or both houses of parliament on one pretext or the other. The smooth functioning of legislatures should be the main agenda of all elected representatives. If any representative attempts to stall proceedings of the assembly or Lok Sabha repeatedly for three times, he should be disqualified and debarred from contesting any election during his lifetime.

6. Persons who hold party positions should not be allowed to administer the government. The parties, which won the majority, can nominate able, efficient, honest and hardworking persons as Prime Minister, Chief Minister or minister, who are all within eligible criteria (as described earlier) from the various fields to run the government. This selected group of ministers will run the government according to the party's directions, policies, advice, and manifestoes. The party president can attend the cabinet meetings and have their say in all government decisions.

7. The chief minister or the Prime Minister should run the government on the advice, directions and policies of the Party. The party will have the power to change either the chief minister or minister at any time and replace him with another able and honest person to head the ministry. But whenever the chief minister is changed, the ministers do not need to resign. Only the new chief minister will take the oath of office.

\section{Government formations -}

\section{A] State government formation}

1. Once election results are announced, the assembly should be immediately convened by the Governor.

2. All newly elected members will be sworn in by the pro-tem Speaker within five days of election results.

3. Then, a new speaker and deputy speaker will be elected by the members.

4. The chief ministers and ministers, selected by the party, which won a simple majority in the assembly, will be sworn in by the Governor. At the same time or later, the ministers selected by the party will be sworn in by the Governor.

5. Those persons who are selected by the party as Chief Minister and Ministers will become members of the assembly but without voting rights in the assembly. They shall continue as members of the assembly without voting rights, as long as they hold office and until replaced by the party. They should not be allowed to participate in any party run programmes, meetings, rallies, events etc. as long as they are in office, they should not be allowed to campaign for the party at any time and during elections. They can campaign for their party through electronic, print, and social media. They can participate in all government functions, ceremonies, events, etc. Their only responsibility is 
governance and administration. That means the quality of governance will not be affected during elections.

6. In case of hung assembly, if no party or the alliance which formed before the elections does not get the simple majority, then the chief minister should be elected by the assembly. Two or more candidates, who are not members of the assembly and selected by their respective parties, can stand for election for chief minister. The speaker should allow only those candidates, nominated by recognised or registered parties, to stand for chief minister post. The person who gets a majority in the assembly will be sworn in as chief minister by the Governor. At the same time or later, the ministers selected by the party will be sworn in by the Governor.

7. That means no MLA either belonging to the party or an independent member, can become either Chief Minister or minister. Every MLA or MP should serve the people of his/her constituency for a full five years.

8. The assembly shall have the right to elect the Chief Minister and not the Governor.

9. The Chief Minister will run the government as long as he/she enjoys the confidence of his/her party and confidence of the majority members of the house.

10. Once elected as Chief Minister, there should be no "vote of confidence" in the assembly.

11. The governor shall not have the right to ask the chief minister to seek a vote of confidence in the assembly.

12. Opposition parties can have the right to move a no-confidence motion at an interval of every four months.

13. To move "no- confidence motion" in the assembly, at least $20 \%$ of the total members of the assembly are required. They should give it in writing to the speaker. The speaker should put this "no confidence motion" to vote on the very next day. It should be put to the vote immediately, without any discussion at all.

14. If "no confidence motion" is defeated in the assembly, then the opposition will have to wait for another four months to move "no confidence motion".

15. If "no confidence motion" is won, then the assembly should immediately elect a new chief minister on the same day.

16. Two or more candidates, who are not members of the assembly and selected by their respective parties, can stand for election as new chief minister.

17. Every member should vote for the candidate put up by his/her party. If he votes against the party, he would be disqualified by the speaker on the complaint received by the party. He shall not be allowed to contest any re-election until the next assembly elections. He/she can contest in midterm elections if the assembly is dissolved before the actual term of the assembly.

18. If the parties failed to elect a new chief minister within 72 hours of the defeat of the government, the Governor should recommend to the Centre for the dissolution of the house. The Centre shall have the right to dissolve the house, put the state under Governor's rule, and recommend to the Election commission to hold elections within three months. Then the election Commission will initiate the process of fresh elections and complete it within three months.

\section{B] Central government formation}

1. Once election results are announced, the Lok Sabha should be immediately convened by the President.

2. All newly elected members shall be sworn in by the pro-tem Speaker within 5 days.

3. Then new speaker and deputy speaker of the Lok Sabha will be elected by the members.

4. The Prime Minister selected by the party, which won a simple majority in the assembly, will be sworn in by the President.

5. Those persons who are selected by the party as Prime Minister and Ministers will become members of the Parliament but without voting rights in parliament. They shall continue as members of parliament without voting rights as long as they hold office and until replaced by the party. They 
should not be allowed to participate in any party-organised programmes, meetings, rallies, events etc. As long as they are in office, they should not be allowed to campaign for the party at any time and during elections. They can campaign for their party through electronic, print, and social media. They can participate in all government functions, meetings, press conferences, ceremonies, events, etc. Their only responsibility is governance and administration. That means the quality of governance will not be affected during elections.

6. In case of hung Lok Sabha if no party or the alliance, which formed before the elections, does not get the simple majority, then the Prime Minister shall be elected by the Loksabha. Two or more candidates, who are not members of Lok Sabha and selected by their respective parties, can stand for election for Prime Minister. The speaker should allow only those candidates, nominated by registered or recognised parties, to stand for Prime Minister. The person, who got majority in Lok Sabha, will be sworn in as Prime Minister by the President. At the same time or later, the ministers selected by the party will be sworn in by the President.

7. That means no MP either belonging to a political party or independent member can become either Prime Minister or minister. Every MP should serve the people of his/her constituency for a full five years.

9. The Prime Minister will run the government as long as he/she enjoys the confidence of his/her party, and majority of Lok Sabha members.

10. Once government is formed with the majority vote in the Lok Sabha, there should be no "vote of confidence" in the Lok Sabha till the end of the term.

11. The President shall not have the right to ask the Prime Minister to seek a vote of confidence in the Lok Sabha in case when the party loses majority due to either withdrawal of support from its coalition party or independent members or split in the party.

12. Only opposition parties, if they think that the government has lost majority", shall have the right to move "no confidence motion" in the Loksabha during its compulsory monthly session. Note Parliament sessions should be held every month from $1^{\text {th }}$ to $13^{\text {th }}$ day of each month, with every Saturday and Sunday being holidays. If any holiday falls between these days, one additional day should be added beyond the $13^{\text {th }}$ of that month. That means there will be 12 sessions each year. In each session there will be a minimum of 10 working days for parliament. The total working days per year will be 120 .

13. Opposition parties can have the right to move a no confidence motion at the interval of every four months.

14. To move "no confidence motion" in the Lok Sabha at least $20 \%$ of the total members of the Loksabha are required. They should give it in writing to the speaker. The speaker should put this "no confidence motion" to the vote on the very next day. It should be put to vote immediately without any discussion at all.

15. If "no confidence motion" is defeated in the Lok Sabha, then the opposition will have to wait for another four months to move "no confidence motion".

16. If "no confidence motion" is won then the Loksabha should immediately elect a new Prime Minister.

17. Two or more candidates, who are not members of the Lok Sabha and selected by their respective parties, can stand for election for the new Prime Minister.

18. Every member should vote for the candidate put up by his/her party. If he votes against the party, he would be disqualified by the speaker or election commission on the complaint received by the party. He shall not be allowed to contest any re-election until the next Loksabha elections. He/she can contest in midterm elections of Loksabha if it is dissolved before the actual term.

19. If the parties failed to elect a new Prime Minister within 72 hours of the defeat of the government, the President should recommend to the Election commission of India to hold general elections within three months. The elections commission will initiate the process of fresh elections and complete it 
within three months. Meanwhile, the last Prime Minister will act as the caretaker Prime Minister until the next Lok Sabha is elected.

21. The Prime Minister, the Chief Minister, Central and state ministers should declare their assets [all movable immovable properties, bank balances, shares and other investments belonging to them, spouses, dependent children and family members] before they take the oath of secrecy. Monthly updates of assets [bought or sold] should be put on the Government website for the general public.

\section{Accountability of legislature}

\section{$100 \%$ transparent administration and governance with zero corruption.}

\section{These prescribed suggestions are for both Parliament houses and state assemblies.}

1. All income and expenditure accounts in all ministries and departments [Except defence, space, Science, research, nuclear technology, etc.] in one month should be put in the Lok Sabha and passed cumulatively in one bill, with simple majority in session of next month. These accounts should be put on the internet for the general public.

2. All land allotments to individuals, companies, trusts, corporations, societies, organisations that are done during the month by the state governments should be put in the respective state assemblies and passed through one bill with simple majority in session of next month. The full details of all land agreements and allotments to industries, individuals, trusts, societies, etc., carried out during the month should be put on the internet for the general public. Every square foot of government land belongs to the 134-crore population. They should have the absolute right to know how and why their elected governments are allotting government lands to industries, individuals, etc.

3. The full details of the various mines allotted anywhere in the countries to companies and individuals, either for captive mining, domestic purpose or for exports, should be put on the government website and passed in the Lok Sabha through one bill with simple majority. All the mining details of the month, like quantity of ores mined, exported ores, internally used ores for domestic industries, stock of the ores mined should be put on the internet for the general public. Individuals and the companies who got licenses for mining should give every day the quantity of ore mined, the quantity of ore sold to domestic companies, and the quantity of ore exported to the foreign countries and put on the government website for the general public. The under reporting of ores mined should be regarded as a non-bailable offence and liable to the punishment of life imprisonment.

4. All the government contracts that are awarded by the Centre of States during the month should be put in Lok Sabha or the state assemblies, and passed through one bill with simple majority in the session of Lok Sabha or state assemblies next month. All the contract agreements should be put on the internet for the general public. For this purpose, every contractor who was awarded a government contract worth over Rs 10 crores should open a business account from any bank for execution of the contract. Every rupee on that work should be spent through cheque, debit card, online transfers, or UPI payments. These business accounts issued by banks for the execution of government contracts should be made available to the general public for viewing the daily account statements at any time. The banks should have a separate portal for the general public for viewing the daily updated statements of these business accounts issued to contractors for execution of government works.

5. The daily progress on all government contracts should be posted on the government website with daily expenditure details on each contract work and video footage. The list of contract works and their business account numbers should be made available on the government websites for the general public so that people can view the updated daily statements of these business accounts 
issued for government works. People should have the absolute right to know how their hard-earned money collected by governments through various taxes is being spent on projects through contractors. Diversion and embezzlement of these funds allotted for government works by the contractors for their personal usages or investments on other assets should be regarded as nonbailable criminal offences with a maximum punishment of life imprisonment.

6. All trade agreement documents [except defence, space, science, technology, nuclear, etc.,] that are executed with any country or industry or organisation during the previous month should be endorsed by the Lok Sabha with simple majority in the session of next month. All these documents should be put on the internet for the general public.

7. Each bilateral or multilateral agreement, executed with any foreign country or world organisation should be endorsed by the Lok Sabha with simple majority and put on websites for general public

8. All government revenues and expenditure accounts[except defence, science, technology, R\&D, nuclear programmes] should be put on different websites according to ministry wise, departmentwise, institution-wise, State-wise, District-wise, village -wise, date-wise, month-wise and year-wise. 9. Day-to-day updating of all government accounts [except defence, science, technology, R\&D, nuclear programmes] according to ministry wise, department-wise, institution-wise, State-wise, District-wise, village-wise, date-wise, month-wise and year-wise, should be available on websites for the general public.

10. All loan agreements executed with foreign governments, organisations, institutions, banks [World Bank, Asian development bank, IMF, etc.,] should be endorsed by the Loksabha with simple majority. Once passed in the parliament, these agreements should also be put on websites for the general public.

11. All government accounts belonging to every ministry, every department, every institution, every organisation, etc., [except defence, science, technology, R\&D, nuclear programmes] should be put on government websites with detailed spending on a day-to-day basis for the general public. There will be no need for the Right to Information Act - RTI. There will be no need for appointment of public committees.

12. The opposition parties shall have the right either to support any bill or abstain from voting during the passage of the bills. But they should not obstruct the passage of any bill or act by slogan shouting and other means of aggressive behaviour in both houses of parliament. The speaker of the Lok Sabha or the Chairman of Rajya Sabha can disqualify any member for disrupting proceedings, showing other means of aggressive behaviour in respective houses of parliament.

\section{Tenure of legislatures and local bodies}

I am suggesting the following tenures for local bodies and legislatures.

Assembly and Loksabha tenure -4 years

Rajya Sabha tenure - 6 years

Corporations and Municipalities -4 years

Mandal/ block presidents, Panchayat presidents -4 years

It should be made mandatory to hold elections for local bodies without postponing them by state governments for one reason or another.

The state election commission should have complete authority to conduct local body elections on schedule, whether the state government agrees to it or not. The local body elections can be postponed only under extreme conditions like pandemic outbreak and floods or in the event of general elections. The local body elections should be conducted 2 months in advance before the term of running boards ends. The bye elections for all vacancies in local bodies, caused due to resignations or deaths, should be conducted for every three months. 


\section{Restructured people representation}

\section{Four tier representations -}

I suggest four tier representations instead of six tier representations in the present system. There will be no ward members for panchayats.

Panchayat shall be considered as a ward in the municipality. Every mandal/block with a population of 1 lakh is to be declared as Municipality.

There shall be direct elections for

I. Panchayat president or ward member for municipality

2. Block/Mandal president or Municipal chairperson and member of Zilla parishat

3. MLA, member of assembly and member of Zilla parishat.

4. MP, Member of Lok Sabha and member of Zilla parishat chairperson.

A] People in rural areas will elect four representatives directly.

1. Village president who is also a ward member in the mandal/municipality.

2. Mandal/block president Chairperson of municipality and member of Zilla parishat

3. MLA member of the assembly and member of zilla parishat

4. MP [MP shall also become the chairperson of the Zilla parishat].

Every parliament constituency should become a district. That means there will be 543 districts. Rural people elect Panchayat, Municipality, assembly and Lok Sabha, and urban people elect ward member/corporator, Corporation chairperson, assembly and Lok Sabha.

B] People in urban areas will elect four representatives directly.

1. Ward member

2. Chairperson/Mayor of Municipal Corporation.

3. MLA member of Municipal Corporation

4. MP [MP shall also act as the chairperson of the Zilla parishat or district board].

The people will elect the village president directly. There will be no ward members if the population of the village is less than 5000. If the village population is more than 5000, it should have two Panchayat presidents and then there will be two ward members from that village in the mandal/block municipality. The village president shall also be the mandal/block municipal member. That means there will be an election for village president who is also a ward member, and for chairperson of the mandal/block municipality.

2. There will be direct election for mandal/block president. The mandal/block presidents shall also act as members of Zilla/district parishat. The mandal/block municipality consists of directly elected mandal/block presidents and village presidents as its ward members. Every village in the mandal/block is a ward area in the mandal/block municipality. Village presidents are mandal/block council members. One of the village presidents will be elected as vice president of the mandal/block municipality.

3. Every parliamentary constituency should be declared as a district/Zilla. That means there will be 543 districts/zillas in India. Every elected Member of Parliament shall also be the chairperson of the Zilla parishat. All the mandal presidents in that zilla/district are Zilla/district parishat members. There will be no separate elections for Zilla/district parishat chairperson posts. Every elected MP shall act as the chairperson of the Zilla/district parishat. The MP will attend parliament sessions from $1^{\text {st }}$ to $13^{\text {th }}$ of every month. The MP, who performs as chairperson of the Zilla/district parishat, will attend the Zilla/district parishat meetings, to be held from $16^{\text {th }}$ to $30^{\text {th }}$ of each month. One person among the mandal/block presidents will be elected as vice chairperson of the Zilla/district parishat.

4. In the case of municipal corporations, people will elect corporators and mayors directly.

The daily expenditure details incurred in village panchayats or Municipalities should be put on websites according to village-wise, ward-wise, city-wise, town-wise, date-wise, month-wise and yearwise for the general public. 
5. All village accounts, zilla parishat accounts and municipal and corporation accounts should be posted on the websites with daily updates of incomes and expenditures. All payments should be carried through cheques or online transfers only. No withdrawal of money in cash form should be allowed.

6. With all government accounts on websites for the general public, there will be no need for the Right to Information Act - RTI.

7. The candidates who want to contest any election should declare their assets [all movable, immovable properties, bank balances, shares and other investments belonging to them, spouses, dependent children and family members] and submit to the Election commission, along with the application to contest elections. If he/she gets elected, monthly updates of assets [bought or sold] should be submitted to the election commission.

\section{This a part of my Digital India project created for the implementation of TOP TAX system.}

Disclaimer. All my suggestions expressed in this document are not intended to hurt the feelings of any person and are not intended to undermine any institution or organisation.

\section{Traditional Copyright - All rights reserved Name - VIJAYA KRUSHNA VARMA \\ Occupation - Research \\ Mobile -9346689919}

Research interests - Banking reforms, water resources management, administrative reforms, educational reforms, tax reforms, health care for all, environment protection, agriculture sector, energy sector etc.

www.vijayakrushnvarma.com 